\title{
В.В. Обыденов
}

\section{ОБСТОЯТЕЛЬСТВА СМЯГЧАЮЩИЕ АДМИНИСТРАТИВНУЮ ОТВЕТСТВЕННОСТЬ В ЮРИСДИКЦИОННОЙ ДЕЯТЕЛЬНОСТИ ПОЛИЦИИ}

3 а время действия КоАП РФ с 2002 г. в него вносились многочисленные изменения и дополнения, ряд из которых способствовал совершенствованию административно-юрисдикционной деятельности органов исполнительной власти. Изучение КоАП РФ показывает, что изменения, внесенные в него за истекший период, преимущественно касались Особенной части. Общая часть данного закона до настоящего времени оставалась практически без изменений, что уже не в полной мере соответствует потребностям юрисдикционной деятельности, осуществляемой различными органами исполнительной власти. К настоящему времени назрели объективные предпосылки внесения определенных корректив в Общую часть КоАП РФ по целому ряду направлений. В частности, необходимо усовершенствовать предписания, содержащие обстоятельства, смягчающие административную ответственность.

Данное положение связано с тем, что, несмотря на большое количество привлекаемых к административной ответственности ффизических и юридических лиц, предписания, касающиеся обстоятельств, смягчающих административную ответственность, практически не учитываются. Подобная практика обусловлена моментами как объективного, так и субъективного характера. К числу моментов объективного характера, которые не позволяют учитывать весь спектр обстоятельств, смягчающих административную от-

DOI: 10.7256/2222-1964.2013.4.9582

При цитировании этой статьи сноска на доі обязательна 
ветственность, относится тот фракт, что данные обстоятельства не дифференцированы, зачастую отсутствует механизм их реализации. Есть и чисто субъективные моменты, способствующие игнорированию учета обстоятельств, смягчающих административную ответственность.

Названные и ряд других положений обусловливают определенные сложности при определении учета и реализации обстоятельств, смягчающих административную ответственность, в деятельности органов исполнительной власти, в целом и полиции, в частности. Как показывает практика, игнорирование обстоятельств, смягчающих административную ответственность, влечет за собой нарушение прав граждан, к которым применяются административные наказания. Кроме того, нарушаются общие правила назначения административных наказаний, определенных КоАП РФ и законами субъектов РФ об административной ответственности.

Несмотря на то, что институт административной ответственности в российском праве исследован достаточно фундаментально, обстоятельства, смягчающие данный вид юридической ответственности, проанализированы весьма фрагментарно. В этой связи исследование института обстоятельств, смягчающих административную ответственность, в юрисдикционной деятельности органов исполнительной власти вызвало объективную необходимость обращения к научной литературе по уголовному праву и другим юридическим наукам.

Обстоятельства, смягчающие и отягчающие административную ответственность, исследовались весьма поверхностно, как правило, в ходе изучения практики реализации административных наказаний ${ }^{1}$. Как показывает практика в механизме назначения административных наказаний весьма значимую роль играют обстоятельства, смягчающие и отягчающие ответственность.

Н.М. Жданов, исследовав в свое время институт обстоятельств, смягчающих административную ответственность, писал: «... объединяет эти обстоятельства то, что они могут существенно влиять на вид и размер взыскания, на ответственность в целом ${ }^{2}$.

\footnotetext{
${ }^{1}$ См.: Ахмедов А.И. Административные взыскания, применяемые органами внутренних дел. - Ташкент, 1988. - С. 48; Бутков А.В. Проблемы применения органами внутренних дел административных наказаний: дис. ... канд. юрид. наук. М., 2005. - С. 39; Дугенец А.С. Административно-юрисдикционный процесс. - М., 2003. - С. 186.

${ }^{2}$ См.: Жданов Н.М. Обстоятельства, смягчающие ответственность за административные правонарушения, в юрис-
}

Административные наказания реализуются в рамках специфических правоотношений, которые в научной литературе получили название «административно-деликтные отношения»³.

Кроме того, в научной литературе обосновывается выделение такой отрасли права, как административно-деликтное право. Это отрасль российского права, объединяющая правовые нормы, регламентирующие общественные отношения, связанные с административными правонарушениями и реализацией административной ответственности. Административно-деликтное право осуществляет охранительную, предупредительную и воспитательную функции ${ }^{4}$.

Административно-деликтное право состоит из ряда структурных элементов, которые получили название правового института.

Как отмечает В.С. Якушев, термин «правовой институт» или «институт права» - в юридической литературе один из наиболее употребляемых терминов. Однако до настоящего времени он не получил достаточной определенности. В самом широком виде правовой институт понимается как нечто среднее между нормой и отраслью права, что, естественно, не отвечает ни теоретическим, ни практическим потребностям ${ }^{5}$. Правовой институт традиционно определяется как совокупность норм, регламентирующих обособленные отношения в пределах той группы общественных отношений, которые составляют предмет отрасли 6 . Нормы, определяющие режим обстоятельств, смягчающих административную ответственность содержатся в ст. 4.2 КоАП РФ.

КоАП РФ не содержит в себе определения обстоятельств смягчающих и отягчающих административную ответственность. В этой связи есть смысл кратко остановиться на определении названных дефиниций.

Так, Н.М. Жданов отмечает, что обстоятельствами, смягчающими ответственность за административное правонарушение, являются выхо-

дикционной деятельности органов внутренних дел (милиции): дис. ... канд. юрид. наук. - М., 1984. - С. 10.

${ }^{3}$ См.: Коваль Л.В. Административно-деликтное отношение. Киев, 1979. - С. 20; Шергин А.П. Проблемы административноделиктного права // Государство и право. - 1994. - № 8-9. - С. 52.

${ }^{4}$ См.: Основные институты административно-деликтного права / под ред. А.П. Шергина. - М., 1999. - С. 14.

${ }^{5}$ См.: Якушев В.С. О понятии правового института // Правоведение. - 1970. - № 6. - С. 61.

${ }^{6}$ См.: Якушев В.С. Указ раб. - С. 61. 
дящие за пределы состава правонарушения и не влияющие на его квалификацию признаки, характеризующие, как правило, личность правонарушителя и определенным образом само правонарушение в сторону уменьшения их общественной опасности либо признаки, характеризующие личность нарушителя и учитываемые в соответствии с требованиями гуманизма, а также с принципами, целями и задачами наказания за административное правонарушение ${ }^{7}$.

В диалектическом единстве с обстоятельствами, смягчающими административную ответственность, находятся обстоятельства, отягчающие административную ответственность.

Исходя из этого, С.С. Кужугет отмечает, что обстоятельствами, отягчающими ответственность за административное правонарушение, являются как лежащие за пределами состава административного правонарушения, так и входящие в него в качестве квалифицирующих признаков, которые повышают общественную вредность деяния и лица, его совершившего, вследствие этого обусловливающие усиление налагаемого на него административного взыскания, а в отдельных случаях дают основание ставить вопрос о привлечении виновного к уголовной ответственности ${ }^{8}$.

На наш взгляд, обстоятельства, смягчающие административную ответственность, могут быть определены как элементы, которые выходят за рамки состава административного правонарушения, тем не менее характеризуют субъект административного правонарушения, объективные признаки административного правонарушения и обязательно должны учитываться при назначении административного наказания в сторону его минимизации.

Несмотря на то, что институт обстоятельств, смягчающих и отягчающих юридическую ответственность, достаточно обстоятельно исследован в теории права, тем не менее следует согласиться с Е.C. Сушковой, которая отмечает, что по ряду положений, касающихся обстоятельств, смягчающих и отягчающих ответственность, отсутствует ясность, в том числе терминологическая, остают-

\footnotetext{
${ }^{7}$ См.: Жданов Н.М. Обстоятельства, смягчающие ответственность за административные правонарушения, в юрисдикционной деятельности органов внутренних дел (милиции): дис. ... канд. юрид. наук. - М., 1984. - С. 10.

${ }^{8}$ См.: Кужугет С.С. Обстоятельства, отягчающие административную ответственность, и их значение в юрисдикционной деятельности органов внутренних дел: дис. ... канд. юрид. наук. - М., 1984. - С. 57.
}

ся нерешенными некоторые вопросы, что может привести к затруднениям при их применении на практике. Именно поэтому немаловажной задачей является теоретическое исследование данного института, выявление существенных признаков и отличительных особенностей смягчающих и отягчающих обстоятельств ${ }^{9}$.

Необходимо отметить, что до недавнего времени институт обстоятельств, смягчающих и отягчающих ответственность преимущественно исследовался в науке уголовного права ${ }^{10}$. Современный период развития законодательства об административных правонарушениях придает существенное значение обстоятельствам, смягчающим и отягчающим административную ответственность ${ }^{11}$.

Так, при назначении административного наказания фризическому лицу учитываются характер совершенного им административного правонарушения, личность виновного, его имущественное положение, обстоятельства, смягчающие административную ответственность, и обстоятельства, отягчающие административную ответственность (ст. 4.1 КоАП РФ). Следует сказать, что обстоятельства, смягчающие административную ответственность, подлежат выяснению в ходе производства по делу об административном правонарушении (ст. 26.1, п. 4 КоАП РФ). Изучение протоколов по делам об административных правонарушениях в различных органах исполнительной власти показывает, что данные обстоятельства практически не выявляются, что, безусловно, отражается на объективности рассмотрения дел об административных правонарушениях. Кроме этого имеется немало других нарушений, которые сказываются на качестве и

\footnotetext{
9 См.: Сушкова Е.С. Развитие института отягчающих /смягчающих юридическую ответственность обстоятельств в современном российском законодательстве // Современные проблемы государства и права. - Н.Новгород, 2003. - С. 73.

${ }_{10}$ См.: Карпец И.И. Отягчающие и смягчающие обстоятельства в уголовном праве. - М., 1959; Кругликов Л. О некоторых обстоятельствах, признаваемых при назначении наказания смягчающими // Советская юстиция. - 1984. - № 5. - С. 10; Клишин Ю. Институт смягчающих обстоятельств в русском дореволюционном уголовном праве // Закон. - 2002. - № 12. С. 93; Курц А.В. Следует ли перечень обстоятельств, смягчающих наказание, оставлять открытым? // Уголовное право. 2004. - № 2. - С. 38.

11 См.: Жданов Н.М. Обстоятельства, смягчающие ответственность за административные правонарушения, в юрисдикционной деятельности органов внутренних дел (милиции): дис. ... канд. юрид. наук. - М., 1984. - С. 10.
} 
объективности рассмотрениях дел об административных правонарушениях.

В этой связи необходимо указать на письмо Генеральной прокуратуры РФ от 27 фревраля 2004 г. № 36-12-2004 «Об организации работы прокуратуры по надзору за исполнением законодательства об административных правонарушениях». В данном документе указывается на целый ряд типичных нарушений, допускаемых в ходе осуществления производства по делам об административных правонарушениях. Применительно к рассматриваемой проблематике в вышеназванном письме Генпрокуратуры РФ указывается, что в ходе осуществления прокурорского надзора проверяется правомерность и обоснованность возбуждения дел об административных правонарушениях; прокурор должен выяснить: все ли требования, предусмотренные ст. 28.2 КоАП РФ, соблюдены при составлении протокола об административном правонарушении и содержатся ли в нем все сведения, необходимые для разрешения дела.

Для того чтобы в протоколе об административном правонарушении объективно нашли свое отражение все обстоятельства, имеющие отношение к соответствующему делу, необходимо в ст. 28.2 КоАП РФ дополнить положением о том, что в протоколе об административном правонарушении должны также отражаться обстоятельства, смягчающие или отягчающие административную ответственность. Данное предписание может способствовать тому, что данные обстоятельства будут выявлены и учтены в ходе производства по делу об административном правонарушении.

Говоря непосредственно об обстоятельствах, смягчающих административную ответственность, необходимо отметить, что согласно Кодексу РФ об административных правонарушениях обстоятельствами, смягчающими административную ответственность, признаются:

1) раскаяние лица, совершившего административное правонарушение;

1.1) добровольное сообщение лицом о совершенном им административном правонарушении;

2) предотвращение лицом, совершившим административное правонарушение, вредных последствий административного правонарушения, добровольное возмещение причиненного ущерба или устранение причиненного вреда;

3) совершение административного правонарушения в состоянии сильного душевного волнения (аффректа) либо при стечении тяжелых личных или семейных обстоятельств;
4) совершение административного правонарушения несовершеннолетним;

5) совершение административного правонарушения беременной женщиной или женщиной, имеющей малолетнего ребенка (ст. 4.2 КоАП РФ).

Судья, орган, должностное лицо, рассматривающие дело об административном правонарушении, могут признать смягчающими обстоятельства, не указанные в законе. Как отмечает А. Шидловский, «... при избрании судом меры наказания из всех учитываемых смягчающих ответственность обстоятельств большую часть (65\%) составили не указанные в законе смягчающие обстоятельства, причем $70 \%$ из них характеризовали личность виновного» ${ }^{12}$.

Ряд специалистов в области уголовного права придерживаются точки зрения о том, что перечень обстоятельств, смягчающих наказание, оставлять открытым нецелесообразно. Как отмечает А. Курц, в ч. 2 ст. 61 УК РФ не содержится каких-либо указаний относительно ограничений в признании судом того или иного обстоятельства смягчающим, что на практике приводит к изменению законодательных фрормулировок, указанных в ч. 1 ст. 61 УК РФ, а также к учету судами в качестве смягчающих таких обстоятельств, которые по степени влияния вряд ли можно поставить в один ряд с обстоятельствами, перечисленными в законе ${ }^{13}$. М.Г. Ушакова, напротив, отмечает, что перечень обстоятельств, смягчающих наказание, необходимо оставить открытым. В этом случае указанные в УК РФ обстоятельства будут выполнять две взаимосвязанные фрункции: обязывающую и ориентирующую ${ }^{14}$.

КоАП РФ, также как и УК РФ, НК РФ, не содержит исчерпывающего перечня обстоятельств, которые могут быть рассмотрены как смягчающие административную ответственность. Данное обстоятельство вполне обоснованно, поскольку в жизни бывают такие обстоятельства, учесть которые закон в полном объеме просто не может. В этой связи необходимо право усмотрения, которое может реализовать субъект, применяющий

\footnotetext{
12 См.: Шидловский Законодательное регулирование учета обстоятельств, смягчающих и отягчающих ответственность // Юстиция Беларуси. - 2004. - № 2. - С. 55.

13 См.: Курц А.В. Следует ли перечень обстоятельств, смягчающих наказание, оставлять открытым? // Уголовное право. - 2004. - № 2. - С. 38. - С. 38.

${ }^{14}$ См.: Ушакова М.Г. Смягчающие наказания обстоятельства в уголовном праве России: автореф. дис. ... канд. юрид. наук. M., 2002. - C. 11.
} 
административное наказание. В научной литературе по административному праву под административным усмотрением понимается определенная степень свободы органа в правовом разрешении индивидуально конкретного управленческого дела, которая представляется в целях принятия оптимального решения по делу ${ }^{15}$.

Применительно к административно-юрисдикционной деятельности М.Ф. Забалуева отмечает, что административное усмотрение является возможностью (способом) органа административной юрисдикции с учетом обстоятельств дела, личности виновного избрать такую меру воздействия, которая при данных условиях может оказать большой воспитательный и предупредительный эфрфект. Возможность административного усмотрения, нашедшая выражение в нормах права, в виде свободы выбора одного из закрепленных за данное правонарушение взысканий, возможность счесть какие-либо обстоятельства смягчающими выступает непременным условием, предпосылкой реализации принципа целесообразности ${ }^{16}$.

В связи с этим институт смягчающих обстоятельств дает возможность реализовывать такой принцип юридической ответственности, как гуманизм. Как отметил Б.М. Лазарев, «гуманизм - важный принцип административной ответственности» ${ }^{17}$.

А.С. Телегин, анализируя производство по делам об административных правонарушениях, говорит о том, что установление обстоятельств важно для правильной оценки личности правонарушителя, степени опасности совершенного им проступка и выбора справедливой меры взыскания ${ }^{18}$.

Как отмечается в научной литературе открытый перечень обстоятельств, смягчающих административную ответственность, позволяет правоприменителю признать в качестве смягчающих обстоятельств, следующие моменты, в частности учесть состояние здоровья лица, которое совершило административное правонарушение, учесть инвалидность - водителя транспортного

15 См.: Коренев А.П. Нормы административного права и их применение. - М., 1978. - С. 73.

16 См.: Забалуева М.Ф. Административная ответственность должностных лиц аппарата управления: дис. ... канд. юрид. наук. - М., 1987. - С. 36.

17 См.: Лазарев Б.М. Административная ответственность. M., 1985. - C.48.

18 См.: Телегин А.С. Производство по делам об административных правонарушениях в органах внутренних дел. - М., 1991. - C. 35. средства, социальные заслуги (наличие государственных наград), положительные характеристики с места работы, важные события, которые произошли в стране (победа национальной сборной, спортивного клуба и т.д.) $)^{19}$.

Кроме того, обстоятельства, смягчающие ответственность, помогают учитывать ряд иных аспектов правонарушения, которые способствовали или сопутствовали совершению административного правонарушения. Следует сказать, что обстоятельства смягчающие, ответственность за административные правонарушения, находятся за рамками соответствующего состава. Как отмечает А.С. Дугенец, обстоятельства, смягчающие и отягчающие, не относятся к числу признаков состава правонарушения, они лежат вне состава и потому не способны оказать какое-либо влияния на определение формализованных рамок наказания за совершенное административное правонарушение. Они не влекут применения нового наказания или иной санкции. Обстоятельства, смягчающие и отягчающие ответственность, способствуют правильному выбору меры административного наказания в пределах санкции конкретной статьи КоАП 20 .

В свою очередь, состав административного правонарушения - это своеобразная правовая модель административного правонарушения, включающая совокупность определенных законом признаков (объективные признаки: объект административного правонарушения, объективная сторона административного правонарушения, субъект административного правонарушения и субъективная сторона административного правонарушения). Несмотря на то, что обстоятельства, смягчающие административную ответственность, находятся за рамками состава административного правонарушения, их учет определяется как практическими, так и социальными аспектами.

Изучение действующего законодательства показывает достаточно разнообразный подход законодателя к определению обстоятельств, смягчающих ответственность.

Так, согласно Налоговому кодексу РФ обстоятельствами, смягчающими ответственность за совершение налогового правонарушения, признаются:

\footnotetext{
19 См.: Жданов Н.М. Обстоятельства, смягчающие ответственность за административные правонарушения, в юрисдикционной деятельности органов внутренних дел (милиции): дис. ... канд. юрид. наук. - М., 1984. - С. 16.

${ }^{20}$ См.: Дугенец А.С. Административно-юрисдикционный процесс. - М., 2003. - С. 186.
} 
1) совершение правонарушения вследствие стечения тяжелых личных или семейных обстоятельств;

2) совершение правонарушения под влиянием угрозы или принуждения либо в силу материальной, служебной или иной зависимости;

3) иные обстоятельства, которые судом или налоговым органом, рассматривающим дело, могут быть признаны смягчающими ответственность (ст. 112 НК РФ).

Согласно Уголовному кодексу РФ смягчающими обстоятельствами признаются:

а) совершение впервые преступления небольшой тяжести вследствие случайного стечения обстоятельств;

б) несовершеннолетие виновного;

в) беременность;

г) наличие малолетних детей у виновного;

д) совершение преступления в силу стечения тяжелых жизненных обстоятельств либо по мотиву сострадания;

е) совершение преступления в результате физического или психического принуждения либо в силу материальной, служебной или иной зависимости;

ж) совершение преступления при нарушении условий правомерности необходимой обороны, задержания лица, совершившего преступление, крайней необходимости, обоснованного риска, исполнения приказа или распоряжения;

з) противоправность или аморальность поведения потерпевшего, явившегося поводом для преступления;

и) явка с повинной, активное способствование раскрытию преступления, изобличению других соучастников преступления и розыску имущества, добытого в результате преступления;

к) оказание медицинской и иной помощи потерпевшему непосредственно после совершения преступления, добровольное возмещение имущественного ущерба и морального вреда, причиненных в результате преступления, иные действия, направленные на заглаживание вреда, причиненного потерпевшему (ст. 61 УК РФ).

Сравнительное исследование законодательства государств СНГ показывает, что в некоторых из них также имеются определенные особенности в определении обстоятельств, смягчающих административную ответственность. В частности, В Кодексе Республики Узбекистан об административной ответственности (КоАО) обстоятельствами, смягчающими административную ответственность, являются:
1) чистосердечное раскаяние виновного;

2) предотвращение виновным вредных последствий правонарушения, добровольное возмещение ущерба или устранение причиненного вреда;

3) совершение правонарушения под влиянием сильного душевного волнения либо при стечении тяжелых личных, семейных или иных обстоятельств;

4) совершение правонарушения под влиянием угрозы, принуждения либо в силу служебной, материальной или иной зависимости;

5) совершение правонарушения несовершеннолетним;

6) совершение правонарушения беременной женщиной или лицом, воспитывающим в одиночку ребенка в возрасте до четырнадцати лет (ст. 31 КоАО Узбекистана).

В Кодексе Республики Беларусь об административных правонарушениях (КоАП) обстоятельствами, смягчающими административную ответственность, признаются:

1) чистосердечное раскаяние фризического лица, совершившего административное правонарушение;

2) предотвращение фризическим лицом, совершившим административное правонарушение, вредных последствий такого правонарушения;

3) добровольное возмещение или устранение причиненного вреда;

4) наличие на иждивении у физического лица, совершившего административное правонарушение, малолетнего ребенка;

5) совершение административного правонарушения вследствие стечения тяжелых личных, семейных или иных обстоятельств;

6) совершение административного правонарушения под влиянием угрозы или принуждения либо в силу материальной, служебной или иной зависимости;

7) совершение административного правонарушения несовершеннолетним или лицом, достигшим семидесяти лет;

8) совершение административного правонарушения беременной женщиной.

В Кодексе Республики Казахстан об административных правонарушениях обстоятельствами, смягчающими ответственность за административное правонарушение, признаются:

1) раскаяние виновного;

2) предотвращение виновным вредных последствий правонарушения, добровольное воз- 
мещение ущерба или устранение причиненного вреда;

3) совершение административного правонарушения под влиянием сильного душевного волнения либо при стечении тяжелых личных и семейных обстоятельств;

4) совершение административного правонарушения несовершеннолетним;

5) совершение административного правонарушения беременной женщиной или женщиной, имеющей ребенка в возрасте до трех лет;

6) совершение административного правонарушения в результате физического или психического принуждения;

7) совершение административного правонарушения при нарушении условий правомерности необходимой обороны, задержании лица, совершившего противоправное посягательство, исполнении приказа или распоряжения;

8) совершение административного правонарушения впервые по неосторожности.

Анализ российского законодательства показывает, что КоАП РФ содержит 6 обстоятельств, смягчающих административную ответственность, УК РФ - 10 обстоятельств, смягчающих уголовную ответственность, НК РФ - 2 обстоятельства. Перечень обстоятельств, смягчающих юридическую ответственность, согласно российскому законодательству не является закрытым. Это означает, что при назначении наказания (административного, уголовного) могут учитываться в качестве смягчающих и обстоятельства, не предусмотренные законом. В частности, смягчающими обстоятельствами могут быть такие обстоятельства, как совершение административного правонарушения под влиянием принуждения или материальной зависимости.

Н.М. Жданов, исследуя институт обстоятельств, смягчающих ответственность за административные правонарушения, говорит о том, что обстоятельства, смягчающие ответственность за административное правонарушение, являются одним из исходных правовых критериев, закрепленных законом, которым надлежит руководствоваться юрисдикционным органам (должностным лицам) при решении вопроса о наложении взыскания за административное правонарушения ${ }^{21}$.

\footnotetext{
${ }^{21}$ См.: Жданов Н.М. Обстоятельства, смягчающие ответственность за административные правонарушения, в юрисдикционной деятельности органов внутренних дел (милиции): дис. ... канд. юрид. наук. - М., 1984. - С. 174.
}

Обстоятельства, смягчающие административную ответственность, могут быть определены как элементы, которые выходят за рамки состава административного правонарушения, тем не менее характеризуют субъект административного правонарушения, объективные признаки административного правонарушения, в связи с чем обязательно должны учитываться при назначении административного наказания в сторону его минимизации.

Учет обстоятельств, смягчающих ответственность за административное правонарушение, позволяет реализовать такие принципы данного вида юридической ответственности, как гуманизм, принцип индивидуализации наказания, а также принцип объективности рассмотрения дела.

Сравнительный анализ отечественного законодательства показывает, что ряд смягчающих обстоятельств совпадает, отличие смягчающих обстоятельств зависит от вида юридической ответственности. Ряд смягчающих обстоятельств, которые закреплены в УК РФ, вполне целесообразно закрепить в КоАП РФ.

В частности, речь идет о таких смягчающих обстоятельствах, как совершение правонарушения в результате физического или психического принуждения либо в силу материальной, служебной или иной зависимости; совершение правонарушения при нарушении условий правомерности необходимой обороны, задержании лица, совершившего преступление (административное правонарушение), крайней необходимости, обоснованного риска, исполнении приказа или распоряжения.

Кроме того, в Кодексе РФ об административных правонарушениях, учитывая опыт, который имеется в некоторых государствах СНГ (Беларусии, Казахстана), целесообразно в качестве смягчающих обстоятельств закрепить следующие обстоятельства. Так, смягчающими административную ответственность обстоятельствами должны признаваться такие обстоятельства, как совершение административного правонарушения лицом, которое достигло общего пенсионного возраста. Помимо этого смягчающим обстоятельством может являться оказание лицом, совершившим административное правонарушение, непосредственно на месте доврачебной помощи потерпевшему в результате административного правонарушения. В частности, такая ситуация вполне возможна при совершении администра- 
тивных правонарушений, предусмотренных ст. 12.24, 12.30 КоАП РФ.

Учет этих обстоятельств может способствовать индивидуализации мер административной ответственности, а также развитию у граждан правосознания и правовой культуры, кроме того, повысит доверие к органам государственной власти, которые реализуют законодательство об административных правонарушениях ${ }^{22}$.

Далее необходимо несколько слов сказать о сфрере, где реализуются обстоятельства, смягчающие административную ответственность. Это сфрера административной юрисдикции. Следует сказать, что на сегодняшний день в доктрине административного права, по сути, сложились две концепции административно-юрисдикционной деятельности. Мы их назовем «широкой» и «ограниченной».

Сторонники «широкого» понимания административно юрисдикции, в частности Д.Н. Бахрах, Ю.М. Козлов, А.П. Коренев, И.В. Панова, Ю.Н. Старилов, Л.Л. Попов, В.Д. Сорокин, понимают под ней вид административно-процессуальной деятельности, осуществляемой во внесудебном либо судебном порядке с целью рассмотрения и разрешения административно-правовых споров и применения административно-принудительных мер, включая не только деятельность по рассмотрению и разрешения дел об административных правонарушениях, но и иные виды деятельности - дисциплинарное производство, производство по жалобам и согласительное производство ${ }^{23}$.

Представители второго, более «ограниченного» по содержанию подхода (А.С. Дугенец, М.Я. Масленников, Н.Г. Салищева, А.П. Шергин, А.Ю. Якимов) в целом понимают под административной юрисдикцией рассмотрение дел об

\footnotetext{
${ }^{22}$ См.: Жданов Н.М. Обстоятельства, смягчающие ответственность за административные правонарушения, в юрисдикционной деятельности органов внутренних дел (милиции): дис. ... канд. юрид. наук. - М., 1984. - С. 10.

${ }_{23}$ См.: Бахрах Д.Н. Административное право. - М., 1997. С. 154; Козлов Ю.М. Административное право Российской Федерации. - М., 1998. С. 315; Коренев А.П. Административное право. Ч. 1. - М., 1997. - С. 212; Панова И.В. Актуальные проблемы административного процесса в Российской Федерации: автореф. дис. ... Д-ра юрид. наук. - Екатеринбург, 2000. С. 8-9; Административное право / под ред. Л.Л. Попова. - М., 2002. - С. 412; Старилов Ю.Н. Административная юстиция: проблемы теории. - Воронеж, 1998. - С. 15; Сорокин В.Д. Административный процесс и административно-процессуальное право. - СПб., 2002. - С. 12.
}

административных правонарушениях и принятие решений по ним в установленном порядке. При этом административно-юрисдикционная деятельность не сводится к порядку рассмотрения и разрешения дел об административных правонарушениях, она включает и деятельность по применению мер принуждения, в том числе мер пресечения, проведение административного расследования ${ }^{24}$.

Анализируя различные мнения, хотелось бы отметить, что ни одна из рассматриваемых точек зрения не противоречит другой: это все лишь разные подходы к одному и тому же явлению, и все они в равной мере заслуживают внимания.

Административно-юрисдикционная деятельность органов исполнительной власти не является новой проблемой как для науки административно-процессуального права, так и в целом для административного права.

Представляется, что разработка понятия (определения) административно-юрисдикционной деятельности органов исполнительной власти, уяснение его содержания и основных признаков позволят научно обосновать возможные пути совершенствования организационной и нормативной основы анализируемой деятельности в интересах правопорядка и законности. Это даст возможность наметить конкретные направления дальнейшего развития законодательства России об административных правонарушениях. Рассмотрение понятия (определения) административно-юрисдикционной деятельности органов исполнительной власти, на наш взгляд, должно отталкиваться от понятийного аппарата, т.е. самого термина «юрисдикция». Термин «юрисдикция» происходит от латинских слов jurisdiction - судопроизводство, jus - право и dico - говорю ${ }^{25}$.

В теории права под юрисдикцией понимают установленную законодательством совокупность правомочий соответствующих государ-

\footnotetext{
${ }^{24}$ См.: Дугенец А.С. Административно-юрисдикционный процесс. - М., 2003. - С. 10; Масленников М.Я. Административно-юрисдикционный процесс. - Воронеж, 1990. - С. 22; Салищева Н.Г. Гражданин и административная юрисдикция в СССР. - М., 1970. - С. 8-21; Шергин А.П. Административная юрисдикция в СССР. - М., 1979. - С. 45; Якимов А.Ю. Статус субъекта административной юрисдикции и проблемы его реализации: автореф. дис. ... д-ра юрид. наук. - М., 1996. C. 18-34.

${ }_{25}$ См.: Российская юридическая энциклопедия. - М., 1999. C. 1102 .
} 
ственных органов разрешать правовые споры и решать дела о правонарушениях, оценивать действия лица или иного субъекта права с точки зрения их правомерности либо неправомерности, применять юридические санкции к правонарушителям ${ }^{26}$.

Т.Н. Сасыков отмечает, что административная юрисдикция является одним из видов юрисдикционной деятельности и обладает всеми признаками последней ${ }^{27}$.

В рамках анализа сущности, структуры и содержания административно-юрисдикционной деятельности органов исполнительной власти представляется заслуживающей определенного внимания точка зрения И.С. Перетерского, считающего, что термин «юрисдикция» образован от словосочетания јus+dicere, которое переводится как «разрешение конфрликта» ${ }^{28}$.

В теории административного права юрисдикция определяется большинством ученых в качестве самостоятельного вида правоохранительной деятельности органов государственного управления ${ }^{29}$.

Отдельные ученые рассматривают административную юрисдикцию как государственновластную деятельность, состоящую в применении закона к юридическим конфрликтам и принятия по ним правовых актов ${ }^{30}$. Некоторые авторы рассматривают административную юрисдикцию как деятельность субъектов государственно-исполнительной власти по разрешению споров между различными субъектами, а также применению мер административного и дисциплинарного принуждения, осуществляемую в административной фороме ${ }^{31}$.

${ }^{26}$ См.: Юридическая энциклопедия. - М., 2004. - С. 406.

27 См.: Сасыков Т.П. Проблемы административной юрисдикции органов внутренних дел: автореф. дис. ... канд. юрид. наук. - М., 2004. - С. 11.

${ }^{28}$ См.: Перетерский И.С. Всеобщая история государства и права. - М., 1945. - С. 74.

29 См.: Попов Л.Л., Шергин А.П. Управление, гражданин, ответственность. - М., 1975. - С. 130; Шергин А.П. Административная юрисдикция. - М., 1979. - С. 45; Додин Е.В. Доказывание в административно-юрисдикционной деятельности органов внутренних дел. - Киев, 1985. - С. 6.

${ }_{30}$ См.: Галаган И.А. Административная ответственность в СССР. Процессуальное регулирование. - Воронеж, 1976. С. 46; Якуба О.М. Административная ответственность. - М., 1972. - C. 124.

${ }^{31}$ См.: Бахрах Д.Н. Административное право России. - М., 2004. - С. 306; Якимов А.Ю. Административно-юрисдикци-
Административно-юрисдикционная деятельность органов исполнительной власти направлена на обеспечение правопорядка и законности в различных сферах государственного управления. Административно-юрисдикционная деятельность является разновидностью управленческой деятельности органов исполнительной власти РФ. Административно-юрисдикционная деятельность направлена на реализацию административно-процессуальных и иных норм. Административно-юрисдикционная деятельность органов исполнительной власти может рассматриваться в контексте осуществления производства по делам об административных правонарушениях, а также осуществления предупреждения и пресечения административных правонарушений.

Исходя из вышеизложенного можно отметить, что административно-юрисдикционная деятельность органов исполнительной власти это определенная нормами административного права деятельность по разрешению административно-правовых споров, а также осуществлению производства по делам об административных правонарушениях. Данная деятельность носит государственно-властный, правоохранительный характер. В этой связи особую важность приобретает процесс выявление обстоятельств, смягчающих административную ответственность.

онный процесс и административно-юрисдикционное производство // Государство и право. - 1999. - № 3. - С. 6. 


\section{Библиографический список:}

1. Ахмедов А.И. Административные взыскания, применяемые органами внутренних дел. - Ташкент, 1988.

2. Бутков А.В. Проблемы применения органами внутренних дел административных наказаний: дис. ... канд. юрид. наук. - М., 2005.

3. Дугенец А.С. Административно-юрисдикционный процесс. - М., 2003.

4. Жданов Н.М. Обстоятельства, смягчающие ответственность за административные правонарушения, в юрисдикционной деятельности органов внутренних дел (милиции): дис. ... канд. юрид. наук. М., 1984.

5. Коваль Л.В. Административно-деликтное отношение. - Киев, 1979.

6. Кужугет С.С. Обстоятельства, отягчающие административную ответственность, и их значение в юрисдикционной деятельности органов внутренних дел: дис. ... канд. юрид. наук. - М., 1984.

7. Костенников М.В., Куракин А.В. Актуальные проблемы административного права. - М., 2013.

8. Шергин А.П. Проблемы административно-деликтного права // Государство и право. — 1994. № 8-9.

\section{References (transliteration):}

1. Ahmedov A.I. Administrativnye vzyskaniya, primenyaemye organami vnutrennih del. - Tashkent, 1988.

2. Butkov A.V. Problemy primeneniya organami vnutrennih del administrativnyh nakazanii: dis. ... kand. yurid. nauk. - M., 2005.

3. Dugenec A.S. Administrativno-yurisdikcionnyi process. - M., 2003.

4. Zhdanov N.M. Obstoyatel'stva, smyagchayushie otvetstvennost' za administrativnye pravonarusheniya, v yurisdikcionnoi deyatel'nosti organov vnutrennih del (milicii): dis. ... kand. yurid. nauk. — M., 1984.

5. Koval' L.V. Administrativno-deliktnoe otnoshenie. - Kiev, 1979.

6. Kuzhuget S.S. Obstoyatel'stva, otyagchayushie administrativnuyu otvetstvennost', i in znachenie v yurisdikcionnoi deyatel'nosti organov vnutrennih del: dis. ... kand. yurid. nauk. — M., 1984.

7. Kostennikov M.V., Kurakin A.V. Aktual'nye problemy administrativnogo prava. - M., 2013.

8. Shergin A.P. Problemy administrativno-deliktnogo prava // Gosudarstvo i pravo. — 1994. — № 8-9. 